\title{
Investigating the Role of Physical Education in Physical Activity Promotion: An Italian Multicenter Study
}

Article in Journal of Physical Activity and Health · March 2015

DOI: 10.1123/jpah.2015-0452

CITATIONS

0

27 authors, including:

Mauro De Santi

Università degli Studi di Urbino "Carlo Bo"

44 PUBLICATIONS 579 CITATIONS

SEE PROFILE

\section{Marco Guida}

University of Naples Federico II

156 PUBLICATIONS 1,144 CITATIONS

SEE PROFILE
READS

53

\section{Francesca Fortunato}

Università degli studi di Foggia

36 PUBLICATIONS 242 CITATIONS

SEE PROFILE

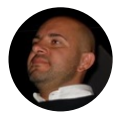

Silvio Tafuri

Università degli Studi di Bari Aldo Moro

169 PUBLICATIONS 868 CITATIONS

SEE PROFILE

Some of the authors of this publication are also working on these related projects: 


\begin{tabular}{l} 
JOURNAL Of \\
Physical Activity \\
\& Health \\
\hline
\end{tabular}

INVESTIGATING THE ROLE OF PHYSICAL EDUCATION IN

PHYSICAL ACTIVITY PROMOTION: AN ITALIAN MULTICENTER STUDY

\begin{tabular}{|r|l|}
\hline Journal: & Journal of Physical Activity \& Health \\
\hline Manuscript ID & JPAH.2015-0452.R1 \\
\hline Manuscript Type: & Article \\
\hline Keywords: & health promotion, physical activity, physical education \\
\hline \multicolumn{2}{|}{} \\
\hline
\end{tabular}

SCHOLARONE $^{\text {m }}$
Manuscripts 


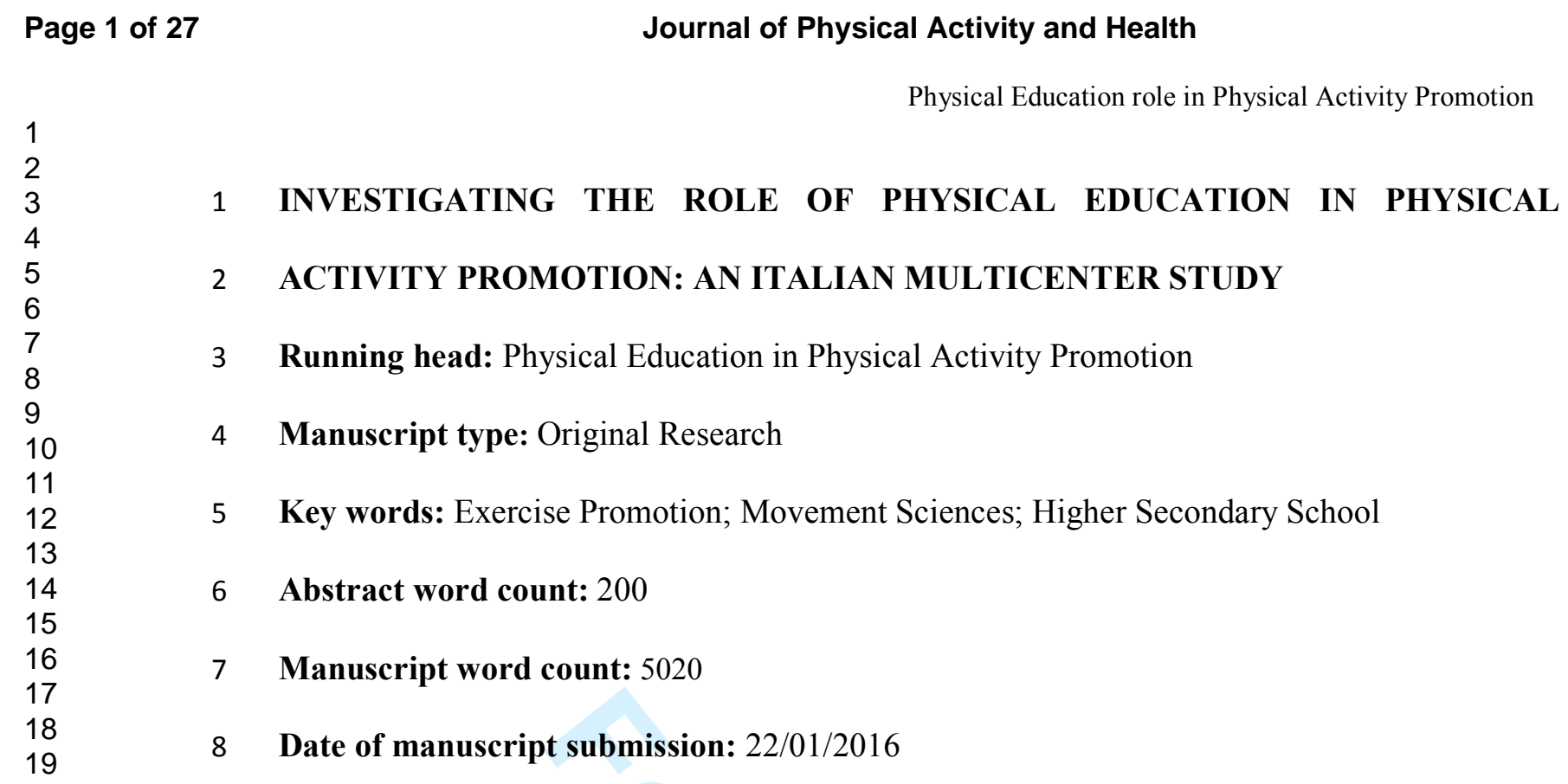

\section{INVESTIGATING THE ROLE OF PHYSICAL EDUCATION IN PHYSICAL}

2 ACTIVITY PROMOTION: AN ITALIAN MULTICENTER STUDY

3 Running head: Physical Education in Physical Activity Promotion

4 Manuscript type: Original Research

5 Key words: Exercise Promotion; Movement Sciences; Higher Secondary School

$6 \quad$ Abstract word count: 200

7 Manuscript word count: 5020

8 Date of manuscript submission: $22 / 01 / 2016$ 
Physical Education role in Physical Activity Promotion

\title{
1 Abstract
}

4 Movement Sciences (MS).

5 Methods. To evaluate the role of PE in higher secondary school in promoting physical activity

6 (PA) and MS career, previous PE experiences and current PA practice were investigated in a

7 sample of Italian freshmen enrolled in different university degree courses.

8 Results. A total of 7,033 questionnaires were completed by students from 14 universities

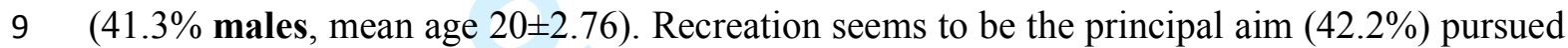

\section{3} during PE lessons, which are based mainly on practical activities (51.7\%). $67.2 \%$ of respondents were satisfied with the PE received during higher secondary school and $51.6 \%$ participated in extra-curricular PA. Current practice of PA was reported by $58.1 \%$ of the sample. Extracurricular activities were associated with choice of MS curricula (OR 2.15, IC95\% 1.85-2.50) and with current practice of PA (OR 1.68, IC95\% 1.51-1.87). Geographical differences concerning lessons organization and satisfaction were registered $(P<.01)$.

Conclusions. To enhance its role in health promotion, PE teaching should be improved by increasing the time allocated to PE and by strengthening the provision of school-based extracurricular PA. 2 4

(1)

\begin{abstract}
2 Background. Physical education (PE) can be considered an instrument for active lifestyle
3 promotion, and PE teachers can motivate youths to continue their studies in the field of
\end{abstract}


1 Introduction

2 There is significant evidence that numerous physical and mental health benefits are 3 associated with physical activity (PA) and exercise. Many studies have documented that

4 PA improves health status, playing a preventive role in cardiovascular diseases, cancer, 5 diabetes and other chronic conditions. ${ }^{1-5}$ In a large review, PA has been found to 6 decrease the incidence of type 2 diabetes of $6 \%$, the risk of colon cancer and breast 7 cancer of $30-40 \%$ and $20-30 \%$, respectively, contributing to reduce the relative risk of 8 death from any cause by about $20-35 \%{ }^{1}$

9 Although it has been widely demonstrated that PA can have many protective effects, only few people are aware of this and meet the guidelines that recommend the daily movement pattern of moderate to vigorous activity to benefit health. ${ }^{6-10}$

Children and adolescents, in particular, frequently do not meet the recommended amount of 60 minutes of PA every day, ${ }^{11-13}$ and PA levels decrease from youth to adulthood. ${ }^{14,15}$ Data reported by the World Health Organization's cross-national survey on Health Behaviour in School-aged children (HBSC) show that in Italy the percentage of youths aged 11-15 years who meet these recommendations ranges from 6.9 to $8.2 \% .{ }^{16}$ In addition, the experience of PA is frequently confined to participation in a few training sessions of sport, which is not enough to ensure the daily requirement of PA. ${ }^{17,18}$

The health benefits of regular PA during adolescence are well known and include a better cardiovascular health and musculoskeletal fitness. PA can also facilitate weight control, prevent or treat symptoms of depression and anxiety, and reduce the likelihood of developing risk factors for chronic disease in adulthood. ${ }^{19}$ Several studies suggest that physically active adolescents often become active adults. ${ }^{20,21}$

Schools are widely recognized as important institutions for the promotion of PA and fitness in children and adolescents. ${ }^{22}$ By providing students with skills to engage in PA and contributing 
Physical Education role in Physical Activity Promotion

to their weekly PA levels, physical education (PE) can play an important role in active

2 lifestyle promotion, as well as providing an instrument to improve motor skills and school

3 performances. ${ }^{14,23-27}$ Furthermore, PE is the only venue where the least active children can

4 experience PA at higher intensities. ${ }^{28}$ It has been shown that positive PE experiences are

5 associated with higher levels of leisure-time PA in young adolescents. ${ }^{29,30}$ In 2012, Sallis et

6 al. coined the term "HOPE - Health Optimizing Physical Education" to highlight the

7 role of $\mathrm{PE}$ in reaching public health goals. In this perspective, the school represents the

8 most cost-effective public health resource to fight inactivity and the PE teacher has the

9 opportunity to provide and promote PA. ${ }^{19}$ Moreover, due to their unique position, physical educators can represent good or bad examples of healthy lifestyles for the students and also a role model to choose studies in Movement Sciences (MS) for their future career path. ${ }^{31}$

Although PE is included in the formalized school curriculum worldwide, time and resources allocated to this teaching are frequently inadequate to promote PA in school-age and lifelong. ${ }^{32,33}$ Where interventions aimed to enhance the role of PE were carried out, benefits 16 for both students and community were registered. ${ }^{34,35}$ Many of these interventions were also carried out in Italy, above all in primary schools where the figure of PE teacher is lacking and the need for an external support in PE is higher. ${ }^{36,37}$ In fact, in Italian primary schools, children aged 6-11 years participate in 1 or 2 hours of curricular PE lessons per week, supported by generalist teachers, while in secondary schools, students (11-19 years) participate in two hours of compulsory $\mathrm{PE}$ per week with teachers who have a specific curriculum and training in $\mathbf{P E} .^{38}$ In addition, national and local sport institutions and associations promote many school-based initiatives of extracurricular PA, in order to introduce different sports and increase the participation in organized sport outside the school. 
1 However, little is known about the features of PE teaching and its efficacy in promoting an

2 active lifestyle in our country.

3 In order to characterize PE teaching in Italy and to investigate its role in promoting PA and an

4 MS career, the Working Group "Movement Sciences for Health" of the Italian Society of

5 Hygiene launched a survey among university students aimed to investigate their previous PE

6 experiences in higher secondary school and their motivations and satisfaction in PE

7 participation. A pilot study was previously carried out involving freshmen in the city of

8 Naples. ${ }^{39}$ The present paper reports the results of the multicenter study aimed to extend the PE

9 evaluation to the whole national area and to highlight possible geographical differences.

The aim is to draft a picture of the current organization of PE in the Italian higher secondary schools and to point out the weaknesses and strengths of PE, as resulting from the beliefs of the students, in order to evaluate whether PE in the Italian school system represents an instrument to enhance active lifestyles or whether substantial changes need to be addressed. Furthermore the study aims to analyze PE as a motivational factor for choosing MS curricula at university level.

\section{Methods}

Participants

A convenience sample of 7,087 freshmen was recruited from different degree courses of 14 universities distributed on the whole Italian territory (Figure 1). Students were selected on the basis of accessibility and proximity with Working Group researchers.

\section{Questionnaire}

An anonymous, self-administered questionnaire was used. Questions included demographic data and information about the current degree course and the secondary school attended 
Physical Education role in Physical Activity Promotion

1 before university enrollment. In order to ensure an accurate recollection of participants'

2 experience, only information about PE undertaken in the last two years of secondary school

3 was collected. This information regarded the type and the main contents of PE lessons, the

4 personal participation in extracurricular PA offered by schools, and the availability of gyms

5 and equipment. For the purposes of this study, the term "recreational activity" indicates

6 any type of non-structured PA performed without the guidance of a teacher or a coach,

7 and "sport activity" indicates structured and supervised PA. Beliefs about PE teaching

8 and personal PE experience were also asked, regarding the aim and the importance attributed

9 to PE and the satisfaction perceived. Furthermore, the current practice of PA was investigated: type of PA, average minutes and number of sessions per week. On the basis of WHO recommendations, a student was defined active if he/she reported at least $150 \mathrm{~min}$ of moderate PA or 75 min of vigorous PA per week. ${ }^{9}$ Beliefs about the influence of PE on the current practice of PA were also investigated.

\section{Data collection procedure}

The questionnaire was previously tested during the pilot study. ${ }^{39}$ In the present study, it was administered during the first semester of the 2013-2014 academic year. At the moment of administration, a researcher explained the purpose of the study and emphasized the anonymity of the responses. Since the questionnaire was anonymous and self-completed, ethical approval was not required. Only the permission of the degree course director was obtained.

\section{Data analysis procedures}

A descriptive analysis was carried out to show the main features of the whole sample. Furthermore, data related to the PE personal experiences of the students and their beliefs about PE were also described and differences among groups coming from North, Center and 
Physical Education role in Physical Activity Promotion

1 South regions of Italy were analyzed; comparisons were performed using the chi-square test

2 with $P<.05$ as significance level.

3 In order to verify if some variables related to the PE received in the secondary school

4 influenced the choice of university course and current PA practice, a multivariate logistic

5 regression analysis was performed. The outcome variables were as follows:

6 - Choice of education area (Outcome 1): a binary variable was built by attributing the

7 value 1 if the students belonged to MS degree courses, and the value 0 otherwise;

8 - PA practice at the time of the investigation (Outcome 2): a binary variable with the $9 \quad$ value 1 if the answer was "yes" and 0 otherwise.

10 All the outcomes were investigated separately using all the explanatory variables regarding 11 PE experience (type of lessons, availability of gym/equipment, participation in extracurricular 12 activities). The explanatory variables were selected by backwards selection using a limit value 13 of $P<.05$ as significance level. Odds Ratios (ORs) and 95\% Confidence Interval (CI) of 14 differences between groups were considered. ORs were weighted for gender and age.

15 All the statistical analyses were performed with the SPSS software version 21.0 for Windows.

17 Results

A total of 7,033 (99.2\% response rate) questionnaires were completed by freshmen of 14 universities. Table 1 describes the distribution of some individual variables of the sample. Participants (41.3\% males) reported a median age of 19 years (mean value $20 \pm 2.76$ years) and came from five education areas. Almost half of the sample was enrolled in Universities 22 from Northern regions of Italy (49.4\%) and came from public secondary schools (94.8\%), mainly from a lyceum $(75.6 \%)$.

Table 2 summarizes the information regarding the organization of PE received at school. 
Physical Education role in Physical Activity Promotion

1 comparing the sub-groups are reported. Overall, in the opinion of the students, the principal

2 aim pursued during PE lessons was mainly recreation and, to a lesser extent, introduction to

3 sports, but the students from central regions reported the achievement of psycho-physical

$4 \quad$ wellbeing as the second main $\operatorname{aim}(P<.01)$. More than half of the sample reported practical

5 activities only during PE lessons and another high percentage of respondents $(>40 \%)$ declared

6 both practical and theoretical lessons, with a similar pattern across the whole Italian territory.

7 However, a higher proportion of students who did not report any type of lessons was

8 registered in Southern regions compared to the others $(P<.01)$. Volleyball is the most

9 frequent activity practised during lessons, both in the whole sample and in the three

10 subgroups, while differences were registered in the distribution of other sports $(P<.01)$.

11 Similarly, theoretical lessons regarded mainly anatomy in all the geographical areas, while

12 other items were differently distributed $(P<.01)$. About $90 \%$ of respondents reported the

13 presence of a gym in the school, with no differences among the three areas $(P=.087)$.

14 Instead, while equipment was also present in the majority of schools, it appeared to be less

15 frequently available in Southern than in Central and Northern regions $(P<.01)$. More than

16 half of the students declared their participation in PA proposed in extra-school time, with no

17 geographical differences $(P=.074)$ (Table 2$)$.

Approximately $60 \%$ of the sample reported current practice of PA, independently of the place

of origin $(P=.201)$ (Table 3). However, in Central and Southern Italy, higher percentages of

20 students reported practising sport at agonistic level, compared with Northern areas $(P<.01)$

21 and this is reflected by the number of hours per week of PA $(P<.01)$. Regarding their

22 beliefs, more than half of the sample reported no or a modest influence of PE on their current

23 personal PA practice, with some differences among areas $(P<.01)$ (Table 3). However, the

24 majority of the sample considered PE learning highly/moderately important, especially in 
1 Southern regions $(P<.01)$. More than two thirds of respondents were satisfied with the PE

2 received, mainly in Northern regions $(P<.01)$.

3 The multivariate regression models built to study the role of high school PE on the subsequent

4 choice of education area and on the participation in PA, showed that, excluding gender, only

5 extracurricular activities performed during the attendance of the secondary school were

6 associated with the choice of MS curricula at university level (OR 2.15, IC95\% 1.85-2.50)

7 and with the current practice of PA (OR 1.68, IC95\% 1.51-1.87) (Table 4). The models were

8 fitted on 6,425 and on 6,355 complete observations, respectively.

9

\section{Discussion}

The present study was carried out to draft a picture of PE teaching in the Italian higher secondary school, as resulting from the beliefs of the students. A first aim was to highlight possible geographical differences in equipment availability, teaching conditions and students' perceptions. Furthermore, the role of $\mathrm{PE}$ in determining the choice of future university studies and PA practice was evaluated.

The very high response rate of the survey $(99.2 \%)$ was probably favored by the active participation of the investigators, constantly present in the classroom during the questionnaire administration in order to explain the aims of the study.

The picture of PE that emerges from the study shows some differences within the country. In general, PE lessons are seen as a moment of recreation in all the geographical areas, with percentages higher in the Center and South in comparison with the North. This can not be considered a negative aspect, but represents a limitation of PE teaching which should also provide information regarding the benefits of PA and the knowledge useful to introduce students to sports and PA outside the school context. In many cases teachers leave students free to undertake non structured physical activities during PE 
Physical Education role in Physical Activity Promotion

1 hours, without the recommended integration between theory and practice, thus failing

2 in part to fulfil their important role as motivators of young people to the practice of

3 PA. $^{22}$ Students from Southern areas declared higher levels of missing PE lessons, in

4 accordance with a lower availability of equipment; this is probably related to the lower

5 satisfaction declared. Nevertheless, this group considers PE highly important, also in

6 addressing the choice to practise PA outside the school context.

7 The greater part of the respondents are currently engaged in PA, although the percentage of

8 active students $(58.1 \%)$ is not consistent with the data provided by the Italian Institute of

9 Statistics in the investigation carried out in 2014 (www.istat.it/it/archivio/128694), which is

10 around $74 \%$ for persons aged $18-24$ years. However, in our sample, females, who always

11 show lower levels of PA compared to their male counterparts, are more represented and, in

12 addition, only students enrolled at University are included. Interestingly, although the

13 declared PA participation is about the same in the different areas of the country, the practice

14 of agonistic activities is significantly higher in the Center and South than in the Northern

15 areas. This could be related to the higher number of students from Movement Sciences

16 courses belonging to the Center and Southern subgroups (data not shown), who could be more

17 inclined to practise agonistic PA.

18 Modalities of PE teaching in the higher secondary school partly affect the behaviors and 19 choices of students; in fact the extracurricular activities offered by schools proved to be 20 related to the choice of University course and to the current practice of PA. This result is in 21 line with what was previously observed in the pilot study and highlights the role of school 22 setting in movement promotion. ${ }^{39}$ On the contrary, the role played by the curricular PE teaching does not seem as important, since it was not associated either with the choice of 24 degree course or with the current participation in PA. In accordance with Sanchez Oliva et 
Physical Education role in Physical Activity Promotion

1 people in relation to the type of the learning environment created by $P E$ teachers, who

2 should favor the motivational processes to determine enjoyment and interest in PA, and

3 stimulate students to increase autonomy, competence and, consequently, satisfaction in

$4 \quad$ PE. $^{40,41}$

5 The results of this study therefore point to the need to enhance PE teaching in the Italian

6 school. This enhancement should be obtained through an increase of the time allocated to PE

7 lessons and through their assignment to well-trained teachers, while extracurricular PA

8 programs should be maintained and enhanced as a useful tool for PA promotion. Sallis et al.

9 highlight that the quality of school PE can be improved through policies, teacher training, use of activities-focused "enhanced" curricula, and small class sizes. ${ }^{19}$ Hills et al. recognize the physical educators as key drivers of physical behavior change of youth, through an interactive teaching style, involving students, families and school staff. ${ }^{22}$ At the same time, our findings show that links with sport societies, sport promotion associations and institutions represents a good strategy and should be strengthened in order to promote sport participation in students and to increase their weekly PA levels. The high participation in school PA, including team and individual sports, academic clubs, and PE, is associated with adulthood $\mathrm{PA}^{42}$ Furthermore, scientific evidences show a positive association between academic performance and PA, with a positive influence on concentration, memory and classroom behavior. $^{43}$

All these aspects have been considered in the recent Government Decree of the Italian Ministry of Education (www.labuonascuola.gov.it/) which resulted from a public consultation about the Italian school system. As regards PE teaching, this document foresees the introduction of the PE teacher with specific curriculum even in primary schools as a health policy, in order to increase social inclusion and promote the healthy and balanced growth of children and teens. ${ }^{44}$ It is, in fact, well established that the expertise of PE staffing is 
Physical Education role in Physical Activity Promotion

1 positively associated with better school PE and PA practices, including those outside the

2 school. $^{45}$ The document has been recently approved by the Italian Parliament and it is hoped

3 that its application will improve PE teaching in Italian schools.

$4 \quad$ Limitations of the study

5 This investigation involved only university students, and degree courses were chosen not 6 randomly, but on the basis of availability in the Universities participating in the study.

7 Moreover, we did not consider the social and economic conditions of the students. Finally, a

8 part of the freshmen included in the North and Center subgroups may come from Southern 9 regions, which is a common occurrence in Italy, and females were more represented. 10 However, the large size of the sample may have reduced the effects of confounding and bias.

\section{Conclusions}

13 The study analyzed PE teaching in the higher secondary school and its possible influence on lifestyles and study choice in young adults. It was carried out on a wide sample recruited on the whole Italian territory and geographical differences were examined.

Our findings showed that PE is still not always considered and endorsed as an instrument for

17 health promotion by students and, apparently, also by teachers. In addition, the lack of time and resources contribute to weaken its role, especially in the Southern area of the country. In anticipation of the desired forthcoming innovations in the Italian school, extra-curricular school-based PA activities, by extending the time and effects of PE, seem to be a useful way to address youths toward active habits and professions. 
Physical Education role in Physical Activity Promotion

\section{References}

2

3

4

1. Warburton DE, Nicol CW, Bredin SS. Health benefits of physical activity: the evidence. CMAJ 2006;174(6):801-809.

2. World Health Organization (WHO). Global Health Risk - Mortality and burden of disease attributable to selected major risks. Geneva: WHO press, 2009.

3. Powell KE, Paluch AE, Blair SN. Physical Activity for Health: What Kind? How Much? How Intense? On Top of What? Ann Rev Pub Health 2011;32:349-365

4. Naci H, Ioannidis JP. Comparative effectiveness of exercise and drug interventions on mortality outcomes: metaepidemiological study. BMJ 2013;347.

5. Hills AP, Street SJ, Byrne NM. Physical Activity and Health: "What is Old is New Again". Adv Food Nutr Res 2015;75:77-95.

6. Kay MC, Carroll DD, Carlson SA, Fulton JE. Public Health Prevention Service, Division of Leadership and Practice, Scientific Education and Professional Development Program Office, Office of Surveillance, Epidemiology, and Laboratory Services, Centers for Disease Control and Prevention, Atlanta, GA. J Phys Act Health 2014;11(4):693-698.

7. Ekblom-Bak E, Olsson G, Ekblom $\mathrm{O}$ et al. The daily movement pattern and fulfillment of physical activity recommendations in Swedish middle-aged adults: the SCAPIS pilot study. PLoS One 2015;10(5)

8. Knox EC, Musson H, Adams EJ. Knowledge of physical activity recommendations in adults employed in England: associations with individual and workplace-related predictors. Int J Behav Nutr Phys Act 2015;12(1):69-76.

9. World Health Organization (WHO). World Health Organization Global Recommendations on Physical Activity for Health. Geneva: WHO press, 2010. 
Physical Education role in Physical Activity Promotion

10. Centers for Disease Control and Prevention. State Indicator Report on Physical Activity, 2014. Atlanta, GA: U.S. Department of Health and Human Services, 2014.

11. Gidlow CJ, Cochrane T, Davey R et al. In-school and out-of-school physical activity in primary and secondary school children. J Sport Sci 2008;26(13):1411-1419.

12. Leoni E, Beltrami P, Poletti G et al. Indagine sulla pratica sportiva e le abitudini motorie dei bambini della scuola primaria del territorio dell'azienda USL di Bologna in relazione ad alcune variabili individuali e ambientali. Ann Ig 2008;20:441-453.

13. Carlson JA, Sallis JF, Chriqui JF et al. State policies about physical activity minutes in physical education or during school. $J$ Sch Health 2013;83(3):150-156.

14. Tammelin T. A review of longitudinal studies on youth predictors of adulthood physical activity. Int J Adolesc Med Health 2005;17:3-12.

15. Kwon S, Janz KF, Letuchy EM et al. Developmental trajectories of physical activity, sports, and television viewing during childhood to young adulthood. JAMA Pediatr 2015;169(7):666-672.

16. Istituto Superiore di Sanità. Health Behaviour in School-aged Children (HBSC) study in Italy: report 2010. Edited by Cavallo F, Giacchi M, Vieno A, Galeone D, Tomba A, Lamberti A, Nardone P, Andreozzi S. Rome, Italy: Rapporti ISTISAN 13/5, 2013.

17. Sacchetti R, Ceciliani A, Garulli A et al. Effects of a two year school based intervention of enhanced physical education in the primary school. J Sch Health 2013;83(9):639-646.

18. Vella SA, Schranz NK, Davern M et al. The contribution of organized sports to physical activity in Australia: results and directions from the Active Healthy Kids Australia 2014 Report Card on physical activity for children and young people. $J$ Sci Med Sport 2015; doi: 10.1016/j.jsams.2015.04.011. 
19. Sallis JF, Carlson JA, Mignano AM. Promoting youth physical activity through physical education and after-school programs. Adolesc Med State Art Rev 2012;23(3):493-510.

20. Telama R, Yang X, Viikari J et al. Physical activity from childhood to adulthood: a 21-year tracking study. Am J Prev Med 2005;28:267-273.

21. Makinen TE, Borodulin K, Tammelin TH et al. The effects of adolescence sports and exercise on adulthood leisure-time physical activity in educational groups. Int J Behav Nutr Phys Act 2010;7:27.

22. Hills AP, Dengel DR, Lubans DR. Supporting public health priorities: recommendations for physical education and physical activity promotion in schools. Prog Cardiovasc Dis 2015;57(4):368-374.

23. Telama R, Yang X, Laakso L et al. Physical activity in childhood and adolescence as predictor of physical activity in young adulthood. Am J Prev Med 1997;13:317-323.

24. Gordon-Larsen P, McMurray RG, Popkin BM. Determinants of Adolescent Physical Activity and Inactivity Patterns. Pediatrics 2000;105:e83.

25. Tudor-Locke C, McClain JJ, Hart TL et al. Expected values for pedometer-determined physical activity in youth. Res Q Exerc Sport 2009;80(2):164-174.

26. Ericsson I, Karlsson MK. Motor skills and school performance in children with daily physical education in school - a 9-year intervention study. Scand J Med Sci Sports $2014 ; 24(2): 273-278$.

27. Cleland V, Dwyer T, Blizzard L et al. The provision of compulsory school physical activity: Associations with physical activity, fitness and overweight in childhood and twenty years later. Int J Behav Nutr Phys Act 2008;29:5-14. 
Physical Education role in Physical Activity Promotion

1 28. McKenzie TL, Lounsbery MA. The pill not taken: revisiting Physical Education

2

3

4 Teacher Effectiveness in a Public Health Context. Res Q Exerc Sport 2014;85(3): 287292.

29. Cox AE, Smith AL and Williams L. Change in physical education motivation and physical activity behavior during middle school. J Adolesc Health 2008;43:506-513.

30. Hagger MS, Chatzisarantis NL, Hein V et al. Teacher, peer and parent autonomy support in physical education and leisure-time physical activity: A trans-contextual model of motivation in four nations. Psychol Health 2009;24(6):689-711.

31. Spittle S, Spittle M. The reasons and motivation for pre-service teachers choosing to specialise in primary physical education teacher education. Aust $J$ Teach Educ 2014;39(5) http://dx.doi.org/10.14221/ajte.2014v39n5.5.

32. Hardman K. The situation of physical education in schools: A European perspective. Hum Movement 2008;9(1):5-18.

33. McKenzie TL, Lounsbery MA. School physical education: The pill not taken. Am J Lifestyle Med 2009;3(3):219-225.

34. Lonsdale C, Rosenkranz RR, Peralta LR. A systematic review and meta-analysis of interventions designed to increase moderate-to-vigorous physical activity in school physical education lessons. Prev Med 2013;56(2):152-161.

35. Dobbins M, Husson H, DeCorby K et al. School-based physical activity programs for promoting physical activity and fitness in children and adolescents aged 6 to 18 . Cochrane Database Syst Rev 2013;2:CD007651.

36. Sacchetti R, Ceciliani A, Masotti A et al. Physical fitness of primary school children in relation to overweight prevalence and physical activity habits. J Sports Sci 2012;30(7):633-640. 
37. Sacchetti R, Dallolio L, Musti MA et al. Effects of a school based intervention to promote healthy habits in children $8-11$ years old, living in the lowland area of Bologna Local Health Unit. Ann Ig 2015;27(2):432-446.

38. European Commission. Physical Education and Sport at School in Europe. Eurydice Report. Brussels: Publications Office of the European Union, 2013.

39. Gallé F, Valerio G, Di Onofrio V et al. Physical education in the Italian higher secondary school: a pilot study based on experiences and opinions of undergraduate students. Sport Sciences for Health 2015;11(1):109-116.

40. Sanchez Oliva D, Sanchez-Miguel PA, Leo FM et al. Physical education lessons and physical activity intentions within Spanish secondary schools: a self-determination perspective. J Teach Phys Educ 2014;33:232-249.

41. Meng How H, Whipp P, Dimmock J et al. The effects of choice on autonomous motivation, perceived autonomy support, and physical activity education. J Teac Phys Educ 2013;32:131-148.

42. Nelson MC, Gordon-Larsen P, Adair LS et al. Adolescent physical activity and sedentary behavior: patterning and long-term maintenance. Am J Prev Med 2005;28:259-266.

43. Trudeau F, Shephard RJ. Physical education, school physical activity, school sports and academic performance. Int J Behav Nutr Phys Act 2008;5:10-21.

44. Romano Spica V, Macini P, Fara GM, Giammanco G, GSMS. Adapted Physical Activity for the Promotion of Health and the Prevention of Multifactorial Chronic Diseases: the Erice Charter. Ann Ig. 2015;27(2):406-414.

45. Turner L, Johnson TG. Physical activity practices in elementary schools and associations with physical education staffing and training. Res Quart Exerc Sport $2014 ; 85: 488-501$. 
Physical Education role in Physical Activity Promotion

1
2
3
4
5

\begin{tabular}{|c|c|c|}
\hline \multicolumn{2}{|c|}{ VARIABLES } & $\mathbf{N}(\%)$ \\
\hline \multirow[t]{2}{*}{ Gender } & Male & $2896(41.3)$ \\
\hline & Female & $4117(58.7)$ \\
\hline \multirow[t]{2}{*}{ Mean age (range) } & & $20(17-25)$ \\
\hline & North & $3476(49.4)$ \\
\hline \multirow[t]{4}{*}{ Geographical area } & Center & $1153(16.4)$ \\
\hline & South & $2404(34.2)$ \\
\hline & Movement Sciences & $1227(17.4)$ \\
\hline & Economics & $581(8.2)$ \\
\hline \multirow[t]{3}{*}{ Education area } & Sciences & $2470(35.1)$ \\
\hline & Medicine & $1414(20.1)$ \\
\hline & Liberal arts & $1341(19.0)$ \\
\hline \multirow{3}{*}{ Higher secondary school type } & Public & $6632(94.8)$ \\
\hline & Private & $362(5.2)$ \\
\hline & Lyceum & $5297(75.6)$ \\
\hline \multirow{3}{*}{$\begin{array}{l}\text { Higher secondary school } \\
\text { qualification }\end{array}$} & Technical school & $1363(19.5)$ \\
\hline & Professional school & $272(3.9)$ \\
\hline & Other & $72(1.0)$ \\
\hline
\end{tabular}

Table 1. Descriptive analysis of the freshmen sample. 


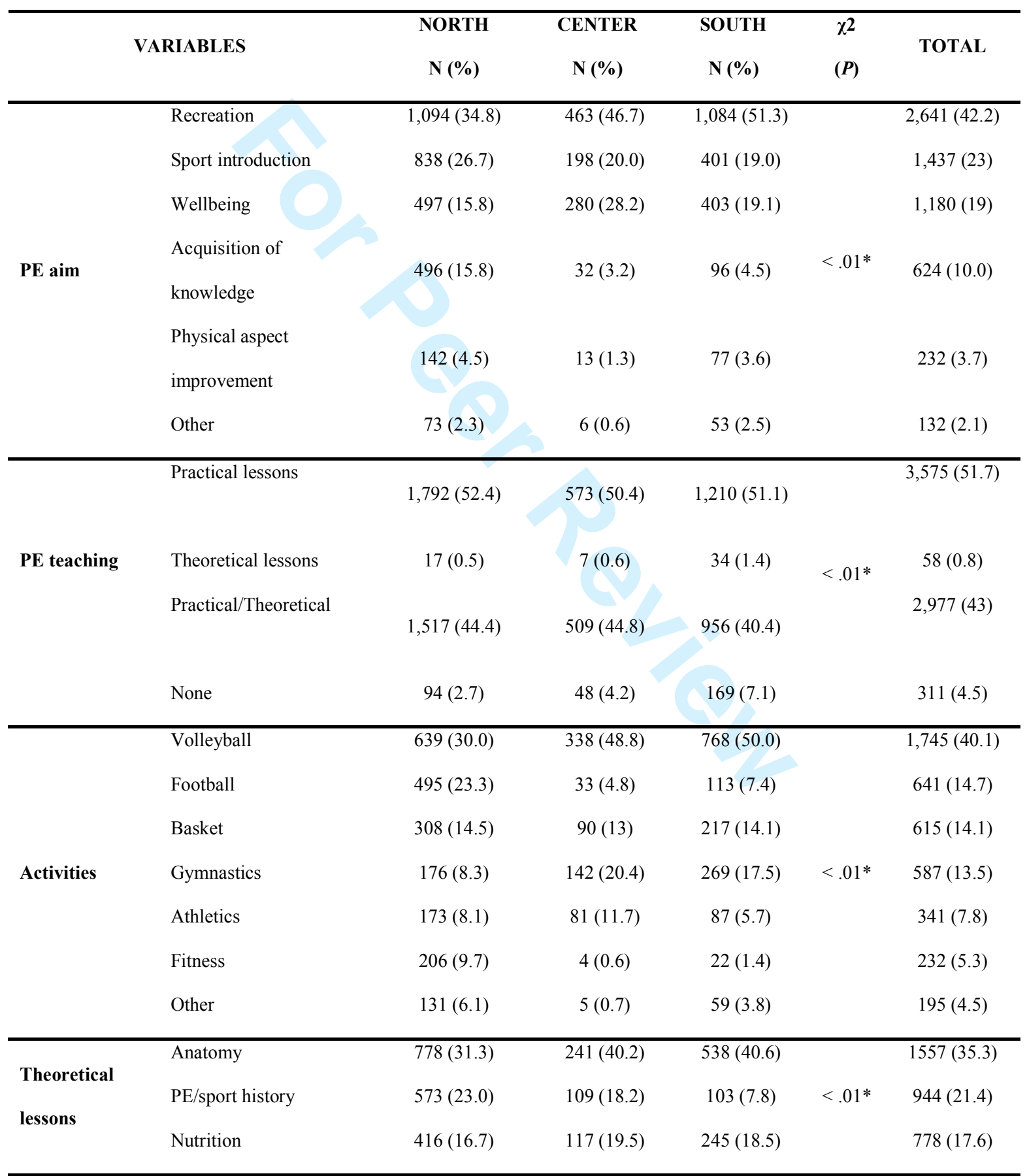


Physical Education role in Physical Activity Promotion

\begin{tabular}{|c|c|c|c|c|c|c|}
\hline & Technical issues & $377(15.2)$ & $40(6.7)$ & $262(19.7)$ & & $595(13.5)$ \\
\hline & Physiology & $342(13.8)$ & $92(15.4)$ & $178(13.4)$ & & 537 (12.2) \\
\hline Presence of a & No & $323(9.4)$ & $116(10.2)$ & $278(11.7)$ & \multirow{2}{*}{.087} & $717(10.3)$ \\
\hline gym & Yes & $3,113(90.6)$ & $1,027(89.8)$ & $2,097(88.3)$ & & $6,237(89.7)$ \\
\hline Equipment & No & $128(4.0)$ & $100(9.4)$ & $388(17.8)$ & \multirow{2}{*}{$<.01 *$} & $616(9.6)$ \\
\hline availability & Yes & $3,033(96.0)$ & 958 (90.6) & $1,794(82.2)$ & & $5,785(90.4)$ \\
\hline \multicolumn{7}{|l|}{ Participation } \\
\hline in extra- & No & $1,716(49.8)$ & $536(46.5)$ & $1,126(47.4)$ & \multirow{2}{*}{.074} & $3,378(48.4)$ \\
\hline curricular & Yes & $1,732(50.2)$ & $616(53.5)$ & $1,251(52.6)$ & & $3,599(51.6)$ \\
\hline activities & & & & & & \\
\hline
\end{tabular}

Table 2. Information about personal PE experience of freshmen in higher secondary school. $\chi^{2}$ test was used to compare subgroups from the three areas.

$\mathbf{P E}=$ Physical Education; $*=\mathrm{p}$ value less than significance level assumed. 


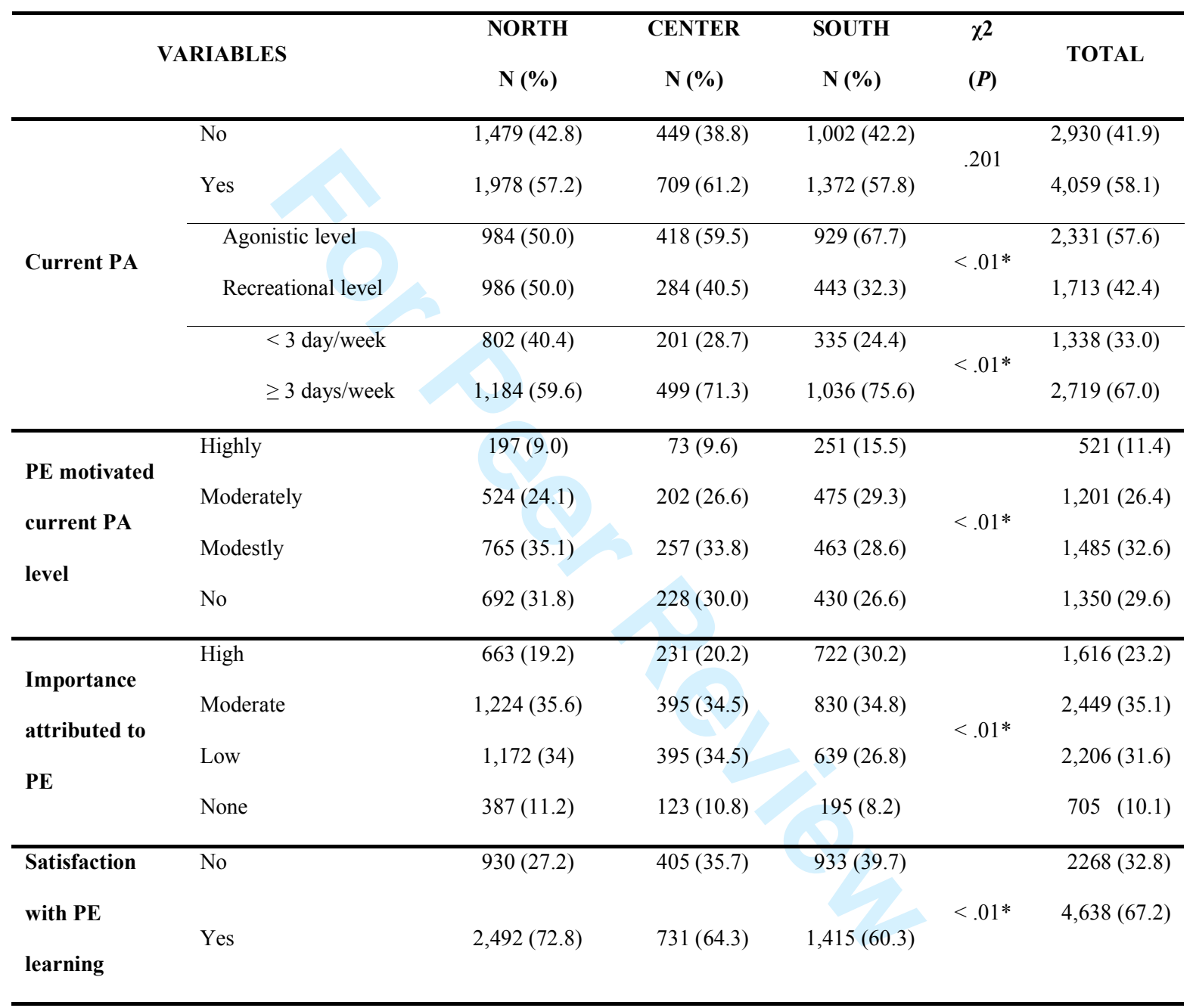

Table 3. Current PA practice and beliefs about personal PE experience of freshmen in higher secondary school. $\chi^{2}$ test was used to compare subgroups from the three areas.

$\mathbf{P E}=$ Physical Education; PA $=$ Physical Activity ${ }^{*}=\mathrm{p}$ value less than significance level assumed. 
Physical Education role in Physical Activity Promotion

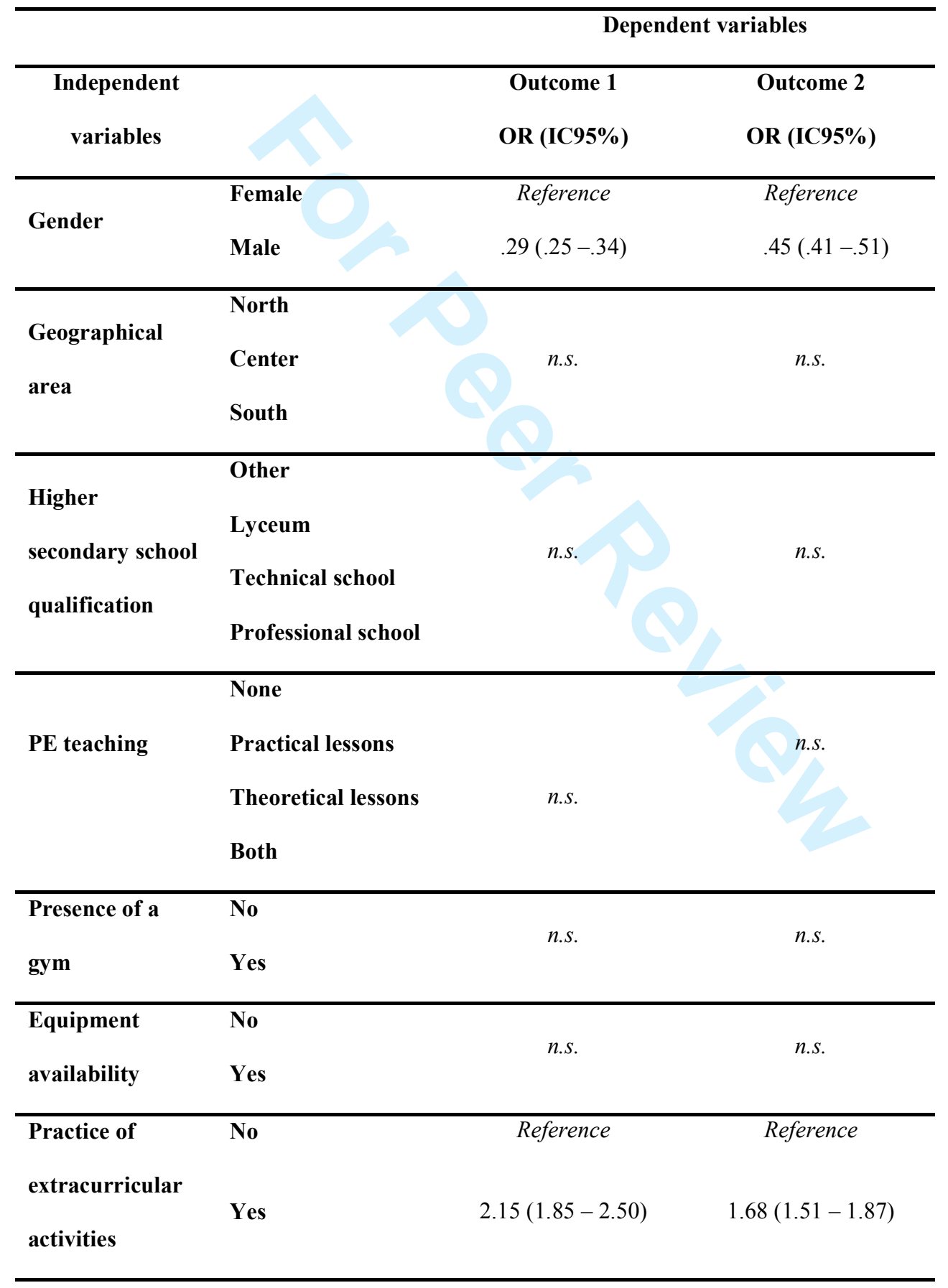


Physical Education role in Physical Activity Promotion

1

2

3

4

5

6

7

8

9

10

11

12

13

14

15

16

17

18

19

20

21

22

23

24

25

26

27

28

29

30

31

32

33

34

35

36

37

38

39

40

41

42

43

44

45

46

47

48

49

50

51

52

53

54

55

56

57

58

59

60

Table 4. Results of the logistic regression analysis. Outcome 1: Choice of education area; Outcome 2: PA/sport practice.

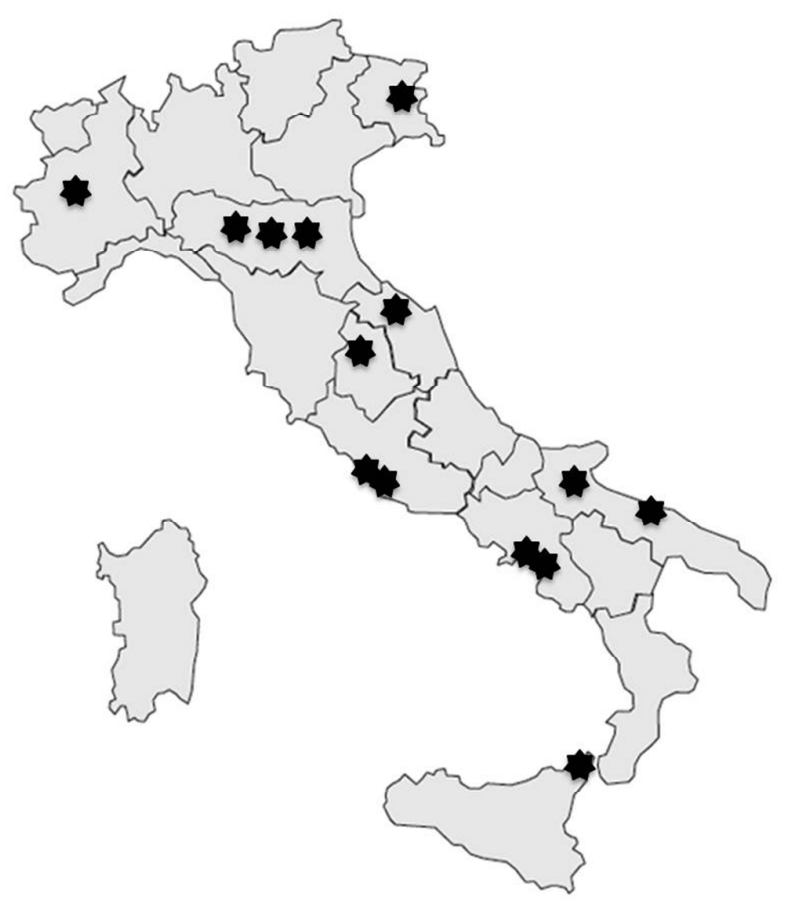

Figure 1. Locations of the universities participating in the study. 


\title{
REVIEWER RESPONSE
}

\author{
Manuscript number: JPAH.2015-0452
}
Manuscript title: INVESTIGATING THE ROLE OF PHYSICAL EDUCATION IN PHYSICAL ACTIVITY PROMOTION: AN ITALIAN MULTICENTER STUDY

\begin{tabular}{|c|c|c|}
\hline Reviewer 1 comment & Author response & Modification \\
\hline $\begin{array}{l}\text { The article was insightful and } \\
\text { provided necessary information } \\
\text { about PE in Italy. My major } \\
\text { concern with the paper overall is } \\
\text { the language. It could use } \\
\text { editorial review for sentence } \\
\text { structure, grammar, and english } \\
\text { translation. }\end{array}$ & $\begin{array}{l}\text { We regret for these shortcomings. } \\
\text { The paper has been } \\
\text { professionally revised for } \\
\text { structure, grammar and English } \\
\text { translation. }\end{array}$ & $\begin{array}{l}\text { Corrections have been made } \\
\text { throughout the whole text. }\end{array}$ \\
\hline $\begin{array}{l}\text { Introduction: } \\
\text { The opening sentence is } \\
\text { misleading. Physical inactivity and } \\
\text { physical activity are two separate } \\
\text { variables and it cannot be } \\
\text { assumed that the lack of physical } \\
\text { activity = physical inactivity. } \\
\text { Please provide a stronger } \\
\text { opening that focuses on physical } \\
\text { activity or the lack there of. } \\
\text { Throughout the introduction, } \\
\text { please use stronger statements } \\
\text { with data to portray the need for } \\
\text { this study and your research } \\
\text { question. For example, newer } \\
\text { information and statistics about } \\
\text { physical activity and its benefits } \\
\text { has been published since } 2009 \text {. } \\
\text { Providing newer information with } \\
\text { percentages strengthens your } \\
\text { argument. }\end{array}$ & $\begin{array}{l}\text { In order to avoid confusion, we } \\
\text { have modified the introduction } \\
\text { and we have provided new } \\
\text { references and data to strengthen } \\
\text { the importance of physical activity } \\
\text { and the motivations for our } \\
\text { research. }\end{array}$ & $\begin{array}{l}\text { The previous opening sentence } \\
\text { has been deleted. New sentences } \\
\text { regarding the benefits of physical } \\
\text { activity providing more recent } \\
\text { epidemiological data have been } \\
\text { included at the beginning of the } \\
\text { introduction (page } 3 \text {, lines } 2-8 \text {; } \\
\text { page } 4 \text {, lines } 5-12 \text { ). }\end{array}$ \\
\hline $\begin{array}{l}\text { Methods: } \\
\text { Opinions or beliefs? Beliefs is the } \\
\text { more common term used for } \\
\text { variables such as motivation, } \\
\text { satisfaction, etc. Throughout this } \\
\text { section, there are a lot of misused } \\
\text { english language terms/phrases } \\
\text { making it a bit confusing. }\end{array}$ & $\begin{array}{l}\text { We have replaced "opinions" with } \\
\text { "beliefs" and we have reviewed } \\
\text { the English language. }\end{array}$ & $\begin{array}{l}\text { The term "opinion" has been } \\
\text { replaced with "belief" and } \\
\text { corrections to English translation } \\
\text { have been made throughout the } \\
\text { whole methods section. }\end{array}$ \\
\hline $\begin{array}{l}\text { Results: } \\
\text { Great response rate. Oddly high - } \\
\text { maybe provide a sentence in the } \\
\text { discussion about why this is so } \\
\text { high. }\end{array}$ & $\begin{array}{l}\text { We have motivated this rate in the } \\
\text { discussion. }\end{array}$ & $\begin{array}{l}\text { A sentence regarding the high } \\
\text { response rate has been added in } \\
\text { the discussion (page 9, lines 14- } \\
\text { 16) }\end{array}$ \\
\hline $\begin{array}{l}\text { Please provide more information } \\
\text { on your definition of recreation vs. } \\
\text { sport and how did you represent } \\
\text { the two on your survey. For } \\
\text { example, you can play volleyball }\end{array}$ & $\begin{array}{l}\text { To avoid misleadings, the two } \\
\text { definitions have been clarified in } \\
\text { the Methods section. }\end{array}$ & $\begin{array}{l}\text { A sentence explaining the } \\
\text { difference of the terms } \\
\text { "recreational activities" and "sport } \\
\text { activities" has been added in the } \\
\text { methods section (page } 6 \text {, lines } 3 \text { - }\end{array}$ \\
\hline
\end{tabular}




\begin{tabular}{|c|c|c|}
\hline Reviewer 2 comment & Author response & Modification \\
\hline $\begin{array}{l}\text { Abstract: } \\
\text { line 9: M has been used as } \\
\text { abbreviation but it has not been } \\
\text { yet introduced in the text }\end{array}$ & $\begin{array}{l}\text { Thank you; The abbreviation has } \\
\text { been eliminated. }\end{array}$ & $\begin{array}{l}\text { "M" has been replaced with } \\
\text { "males" (page 2, line 9). }\end{array}$ \\
\hline $\begin{array}{l}\text { Introduction: } \\
\text { p. } 3 \text { line } 6: \text { In the second sentence } \\
\text { is written that "only few people } \\
\text { know and meet..." It is not clear } \\
\text { what do you mean, please } \\
\text { explain. }\end{array}$ & $\begin{array}{l}\text { Right, it was confusing. We have } \\
\text { changed the sentence. }\end{array}$ & $\begin{array}{l}\text { The term "know" has been } \\
\text { replaced with "are aware of this". } \\
\text { (page } 3 \text {, line 10). }\end{array}$ \\
\hline $\begin{array}{l}\text { p.3 lines 22-24: The authors in the } \\
\text { sentence started as: "by providing } \\
\text { students..." concluded that it is } \\
\text { "an instrument to progress better } \\
\text { in the educational career" and } \\
\text { refers to the } 5 \text { cited articles. I'm } \\
\text { not sure which (if any) is about } \\
\text { this issue, because, titles show } \\
\text { only connections with first part of } \\
\text { those sentence ("important role } \\
\text { for active lifestyle promotion"). }\end{array}$ & $\begin{array}{l}\text { The term which was used was not } \\
\text { correct: it has been replaced. }\end{array}$ & $\begin{array}{l}\text { The term "educational career" has } \\
\text { been changed with "school } \\
\text { performance" and a more specific } \\
\text { reference has been added (page } \\
4 \text {, lines } 2 \text { and } 3 \text { ). }\end{array}$ \\
\hline $\begin{array}{l}\text { p.4 line } 2-4 \text { I would like to suggest } \\
\text { that PE teachers also could be } \\
\text { the role models for the students } \\
\text { as good or bad examples of } \\
\text { healthy lifestyles. }\end{array}$ & The concept has been included. & $\begin{array}{l}\text { The role of PA teachers has been } \\
\text { better explained with the help of a } \\
\text { new reference (page } 4 \text {, lines } 5 \text { - } \\
\text { 12). }\end{array}$ \\
\hline $\begin{array}{l}\text { p.4 line } 10-11 \text { I'm not sure what } \\
\text { for authors mean: "specific } \\
\text { traning" for PE teachers. It could } \\
\text { mean quite different for specialist } \\
\text { from different countries with } \\
\text { different PE curriculum; Please } \\
\text { specify. }\end{array}$ & $\begin{array}{l}\text { We referred to the lack of the } \\
\text { figure of physical education } \\
\text { teachers in the primary school. } \\
\text { The sentence has been } \\
\text { rephrased. We hope that now the } \\
\text { concept appears more clear. }\end{array}$ & $\begin{array}{l}\text { The lack of the physical education } \\
\text { teacher in the Italian primary } \\
\text { school has been highlighted in the } \\
\text { sentences at page } 4 \text {, lines } 17-22 \text {. }\end{array}$ \\
\hline $\begin{array}{l}\text { p.4 line } 18 \text { I don't understand the } \\
\text { phrases: "the culture of PA ...", I } \\
\text { couldn't find such connection in } \\
\text { literature. }\end{array}$ & $\begin{array}{l}\text { Right, that was a confusing } \\
\text { expression. }\end{array}$ & $\begin{array}{l}\text { We have replaced "culture of PA" } \\
\text { with "active lifestyle" (page } 5, \\
\text { lines } 1 \text { and } 2 \text { ) }\end{array}$ \\
\hline $\begin{array}{l}\text { METHOD } \\
\text { p.5 line } 20 \text { You mention that you } \\
\text { asked in your questionnaire about } \\
\text { current PA practice according to } \\
\text { WHO recommendation, but in } \\
\text { table we have also information } \\
\text { about days/week - it was extra } \\
\text { added question? }\end{array}$ & $\begin{array}{l}\text { It's right. In the Methods section } \\
\text { we have better explained the } \\
\text { corresponding items of the } \\
\text { questionnaire. }\end{array}$ & $\begin{array}{l}\text { A sentence explaining what was } \\
\text { asked to the students about } \\
\text { current PA has been added in the } \\
\text { Questionnaire section (page } 6 \text {, } \\
\text { lines 9-10). }\end{array}$ \\
\hline $\begin{array}{l}\text { p.6 line } 2 \text { I wonder if the month of } \\
\text { the academic year (e.g. October - } \\
\text { December) plays any role in } \\
\text { differentation of the level of PA in } \\
\text { Italy, because it is important factor } \\
\text { particularly in north part of the } \\
\text { Europe? }\end{array}$ & $\begin{array}{l}\text { We carried out the investigation in } \\
\text { the first semester of the academic } \\
\text { year to collect among freshmen } \\
\text { information about their recent } \\
\text { experiences at school. In the } \\
\text { questionnaire we asked } \\
\text { information about their general PA } \\
\text { levels, without seasonal } \\
\text { differences. Moreover, this item is } \\
\text { interesting and could be } \\
\text { examined in further studies. }\end{array}$ & \\
\hline $\begin{array}{l}\text { RESULTS } \\
\text { Generely comment: } \\
\text { The authors built the multivariate }\end{array}$ & $\begin{array}{l}\text { We used as explanatory variables } \\
\text { only those related to PE } \\
\text { experiences in order to evaluate }\end{array}$ & \\
\hline
\end{tabular}


